\title{
Tissue disinfection for preparation of Dendrobium in vitro culture
}

\author{
Jaime A. Teixeira da Silva ${ }^{1 *}$, Budi Winarto ${ }^{2 * *}$, Judit Dobránszki ${ }^{3 * * *}$, \\ Jean Carlos Cardoso ${ }^{4 * * *}$, Songjun Zeng $5 * * * * *$
}

${ }^{1}$ P. O. Box 7, Miki-cho post office, Ikenobe 3011-2, Kagawa-ken, 761-0799, Japan

${ }^{2}$ Indonesian Ornamental Crops Research Institute (IOCRI) Jln. Raya Ciherang, Pacet-Cianjur 43253, West Java, Indonesia

${ }^{3}$ Research Institute of Nyíregyháza, University of Debrecen

Nyíregyháza, P.O. Box 12, H-4400, Hungary

${ }^{4}$ Department of Rural Development, Centro de Ciências Agrárias, UFSCar

Via Anhanguera, km 174, CP 153, CEP 13.600-970, Araras City, Brazil

${ }^{5}$ Key Laboratory of South China Agricultural Plant Molecular Analysis and Gene Improvement South China Botanical Garden, Chinese Academy of Sciences, 510650, China

\begin{abstract}
Establishing an aseptic in vitro culture for Dendrobium, or for any plant in fact, is the most important step towards developing an effective in vitro tissue culture including micropropagation protocol. Success in initial aseptic culture will contribute to the successful production of in vitro cultures that may involve the initiation or formation of callus and/or protocorm-like bodies (PLBs), the induction, regeneration or multiplication of shoots, and the preparation and proliferation of plantlets suitable for acclimatization. The initiation of an aseptic culture is closely related to the appropriate selection of an explant source and its preparation, including its (in vivo) pre-treatment if necessary and subsequent disinfection procedures. Care in the choice of explant and the application of an appropriate disinfection protocol can successfully reduce, or eliminate, contamination in in vitro cultures while reducing the negative impact on plant tissues and plantlet regeneration. Many unique aseptic culture procedures for Dendrobium genus have been reported in the literature, very often specific to particular tissues or genotypes, and this review not only highlights the details of such protocols, but also provides practical advice for novice - and even seasoned - orchidologists who wish to research Dendrobium in vitro, although it is cautioned that there is currently no universal aseptic culture procedure that can be applied to all conditions, all explants or all genotypes.
\end{abstract}

Key words: aseptic culture, contamination, Dendrobium, disinfectant, disinfection, explant source, procedure

EX VITRO TO IN VITRO: NEED FOR SURFACE DISINFECTION OF PLANT TISSUES FOR THE ESTABLISHMENT OF DENDROBIUM IN VITRO CULTURES

The most important aspect in the establishment of an effective tissue culture system from explants or plant parts derived from ex vitro material, such as greenhouse or field-grown plants, is the disinfection process (George and Debergh 2008). Although it is more likely that field-grown plants will contain more soil- and air-borne contaminants than greenhousegrown plants (Niedz and Bausher 2002), and that conventionally soil-grown plants will have a higher

Corresponding authors: *jaimetex@yahoo.com (J.A. Texeira da Silva),**budi_winarto67@yahoo.com (B. Winarto), ***dobranszki@freemail.hu (J. Dobránszki),****jeancardosoctv@gmail.com (J.C. Cardoso), *****zengsongjun@scib.ac.cn (S.-J. Zeng). 
level of infection by microorganisms than plants grown in hydroponic culture, in all instances, plant material needs to be prepared for in vitro culture, usually in three steps after initial washes and removal of coarse contaminants (Hall 1999): (a) treatment with a disinfectant solution (e.g., 70\% ethanol), then either washing in sterile distilled water (SDW) or not; (b) treatment with a solution of another disinfectant (e.g., sodium hypochlorite $(\mathrm{NaOCl})$ ) and finally (c) rinses in SDW at least three times. There are different variations in the type, order and concentration of disinfectants used, their combinations and their exposure period (Hall 1999, Onwubiko et al. 2013). Aspects such as age of the donor plant, temperature, relative humidity $(\mathrm{RH})$, photoperiod, light intensity, irrigation and fertilization, as well as the type and size of the explant, topophysis, genotype, the season when explants were collected, length of disinfection and concentration of disinfectant will all affect the outcome of the disinfection process, explained in more detail in the next section of this review (Traore at el. 2005, George and Debergh 2008, Dobránszki and Teixeira da Silva 2010, Mihaljevic et al. 2013). The primary objective of disinfection procedures is to find a balance between reducing infection and explant survival and regeneration, which are strongly affected by the physiological state of the explants and the disinfectant used because they are often toxic to plant cells. The rapid development of explants, or their etiolation, can cause explant tissues to become thinner, causing disinfectant to penetrate deeper inside the tissues (Traore et al. 2005, Jan et al. 2013). The depth to which a disinfectant can penetrate a tissue is also important, and may be more important for tissues such as root tips or tuberous organs which are heavily exposed to soil microorganisms than for organs such as anthers that may be protected by other surrounding tissues such as petals (Sugii 2011). An understanding of these factors can determine the success of growth, regeneration or germination since this will undoubtedly be linked to the level of contamination.

Using these principles, this review seeks to find how disinfection procedures have been used to prepare in vivo-derived plant material for in vitro culture in Dendrobium since the in vitro environment serves as an important tool for multiple biotechnological advances, symbiotic and asymbiotic seed germination, and molecular advances, including genetic transformation (Teixeira da Silva et al. 2015a, 2015b, 2015c, 2016).
Dendrobium is one of the largest orchid genera, with an estimated 1400 species (Jin et al. 2009), and has both ornamental and medicinal importance (Takamiya et al. 2011), and thus serves as an optimal plant for investigating this topic since several dozen studies on its in vitro culture have been conducted. In commercial production, well-established protocols have been developed from initial trial and error (Teixeira da Silva and Winarto 2015, 2016), but for novice orchidologists or plant scientists seeking to establish initial Dendrobium in vitro cultures from in vivo material will not easily navigate the large literature to understand how best to treat material to establish an initial in vitro culture. This review thus serves also an extremely important practical purpose: to survey and examine this vast literature, to analyse and determine the conditions that would allow for tissues from various sources and genotypes to be sufficiently disinfected to allow for subsequent regeneration to take place. Three studies involving disinfection procedures have emerged for the Dendrobium genus in 2015 and until March, 2016.

\section{IN VIVO CONDITIONS OF DONOR PLANTS AND EXPLANT CHOICE}

Most authors working with Dendrobium in vitro cultures grew donor plants in pots in a greenhouse (Malabadi et al. 2005, Sujjaritthurakarn and Kanchanapoom 2011, Kumari et al. 2013), glasshouse (Asghar et al. 2011, Paul et al. 2012), or net house (Lone et al. 2008, Dohling et al. 2012, Vijayakumar et al. 2012). Fruits and seeds have also been collected from native wild environments, such as D. huoshanense (Luo et al. 2009) and D. densiflorum (Luo et al. 2008) or from botanical gardens (Pradhan et al. 2013) (Tab. 1). All of these growth environments are not free from microbial contamination, and must thus be treated (disinfected) before they can be used in an in vitro environment, thus favouring the growth of plant tissue over microbial development.

The source, size and age of explants are some of the factors that influence the success of disinfection. Kumari et al. (2013) used the shoots of $D$. Sonia 'Earsakul', 8-12 cm in length and with 3-5 nodes collected from 2-3 weeks-old shoots ('keikies'), as explants to initiate an aseptic culture. In their study, 66.7 to $100 \%$ of explants survived (2.33 shoots per explants with BA at $4.0 \mathrm{mg}$ $\mathrm{dm}^{-3}$ ). Ferreira et al. (2006), who used lateral shoots $8-\mathrm{cm}$ long arising from the base of adult plants of D. 'Second Love' (Nobile type), found that about 
$20 \%$ of explants were contaminated and that only $60 \%$ of buds developed into shoots. Asghar et al. (2011), who also used 8-cm long shoots to culture D. nobile 'Emma White', observed only 22.5\% explant survival in the best treatment that used 8 min exposure of explants to $10 \% \mathrm{NaOCl}$ (active chlorine 6-14\%) with continuous agitation, followed by 4-5 washes, but a high level of contamination was observed: $42.5 \%$ bacterial contamination and $30 \%$ fungal contamination. In $D$. 'Zahra FR 62', $0.4-\mathrm{cm}$ long shoot tips were used by Winarto et al. (2013) as the explant to initiate protocorm-like body (PLB) formation. PLBs were subcultured every 15 days, with $85 \%$ of explants successfully producing green callus in the basal part of explants; initially, callus was green to dark green and compact then became friable in the next subculture and produced PLBs easily, and only $15 \%$ of explants were contaminated by bacteria and/or also suffering from browning (Winarto et al. 2013). In liquid culture, there is abrasion between the surfaces of pieces of callus leading to callus browning, caused by phenolic compounds (Kaewubon et al. 2015) and the application of disinfectants alters the color of explants from green to pale green/ whitish, serving as an indicator of tissue damage (Fig. 1F-H). A similar explant source, size and treatment (see Fig. 1C-E), but with slightly higher explant responsiveness $(87 \%)$, was recorded for D. 'Gradita 31' (Winarto and Rachmawati 2013). The intersection between suitable explant choice, disinfection procedure and the elimination of browning, which typifies young Dendrobium callus cultures (Kaewubon et al. 2015), will determine the success of the callus or shoot induction route. Although the procedures described in Table 1 by Winarto et al. are effective for several cultivars, it has not been tested for all cultivars.

Numerous papers (Tab. 1) have described the environmental conditions in which donor plants are optimally grown, obtained and prepared. Lo et al. (2004) indicated that D. tosaense plants collected from natural environments in Taiwan were cultivated in pots $13.5 \mathrm{~cm}$ in diameter and $10.7 \mathrm{~cm}$ in height, containing tree fern as a substrate; plants were maintained in a greenhouse with $70 \%$ $\mathrm{RH}$ and $25 / 20^{\circ} \mathrm{C}$ day/night temperature. In these conditions, 12-week-old fruit capsules that formed after hand pollination produced the highest number of seedlings in $1 / 2 \mathrm{MS}$ medium than capsules of other ages (8-, 9, -10-, 11-, 13-, 14-weeks-old) and other media (MS, KC, VW). D. nobile plants collected from the wild in India were used as donor plants, cultured in pots and grown under glasshouse conditions. Shoot tips $0.5-0.8 \mathrm{~cm}$ in length were harvested from donor plants and used as the explant source (Malabadi et al. 2005). Pseudobulbs of D. microbulbon collected from the forests of South Gujarat (India) were used as the primary explant source (Sharma et al. 2007). Mature fruit capsules of D. densiflorum collected from Yunnan province, China were used as the explant source (Luo et al. 2008). D. transparens plants were collected from their natural habit in Imphal (India) and kept under netshade which cut $50 \%$ sunlight. Flowers were hand pollinated on the second day of anthesis since flowers only last for 3-5 days and capsules were harvested 120 days after pollination and used as donor explants for in vitro seed germination (Sunitibala and Kishor 2009). D. nanum plants, collected in the KMTR region, South India, were maintained in a greenhouse and $5-\mathrm{cm}$ shoots were used as the explant source (Maridass et al. 2010). In Shillong, India, healthy plants of $D$. chrysanthum were planted in pots and grown in a greenhouse, and after flowers were hand pollinated, and old (8 months) pods were used as explants (Hajong et al. 2010). Three-month-old mature and well-developed D. chrysanthum pods were used as the explants for seed germination experiments (Sujjaritthurakarn and Kanchanapoom 2011). Old (15 months) fruit capsules of $D$. aphyllum were collected from wild habitats in Sarisha, India (Dutta et al. 2011). D. chrysanthum, D. hookerianum and D. longicornu plants were collected from Meghalaya, India, grown in a glasshouse and stem explants $(1-2 \mathrm{~cm}$ long), each comprising a node and axillary bud, were used as the explants (Dohling et al. 2012). Paul et al. (2012) used purplish-green fruit capsules of D. hookerianum collected after 8-9 months from pollination. Vijayakumar et al. (2012) used hand pollination in the second day after anthesis to obtain fruits from plants of $D$. agregattum collected from a natural environment and grew them under a shade net house (75\% shade). Shoots $8-12 \mathrm{~cm}$ long with 3-5 nodes were harvested from 2-3-weeks-old keikies of greenhouse-grown mother plants served as suitable explants (Kumari et al. 2013).

For D. 'Zahra FR 62' and D. 'Gradita 31', maintaining donor plants under a shade glasshouse $(75 \%)$ in a mixture of Cycas rumphii bulk and wood charcoal $(1: 1, \mathrm{v} / \mathrm{v})$ by watering every morning at 7.00-8.00 am and fertilizing them using $2 \mathrm{~g}$ $\mathrm{dm}^{-3}$ of $\mathrm{N}: \mathrm{P}: \mathrm{K}, 20: 20: 20$ and applying $2 \mathrm{ml} \mathrm{dm}^{-3}$ BioSugih liquid fertilizer twice a week successfully induced vegetative growth of the donor plants and 


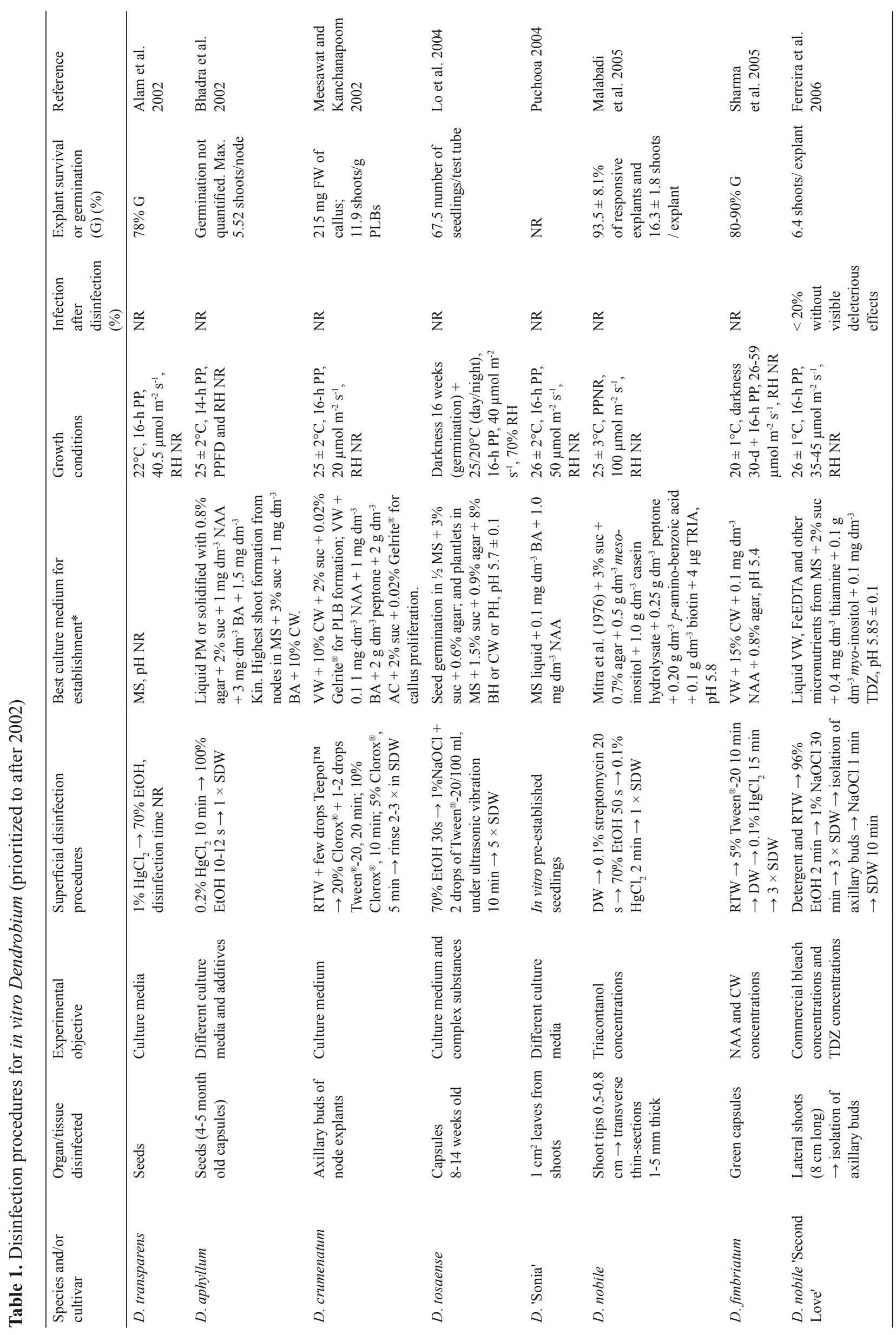




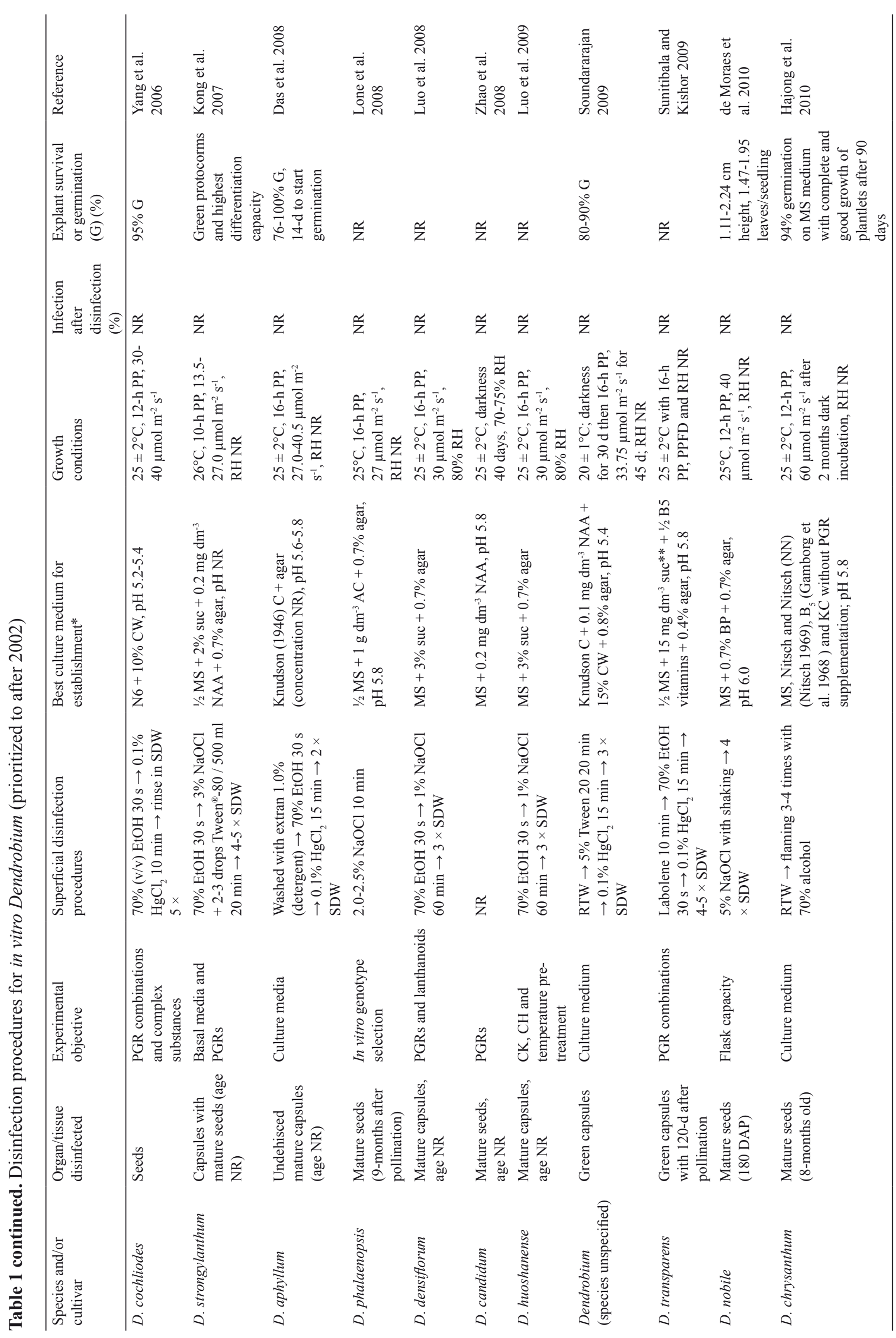




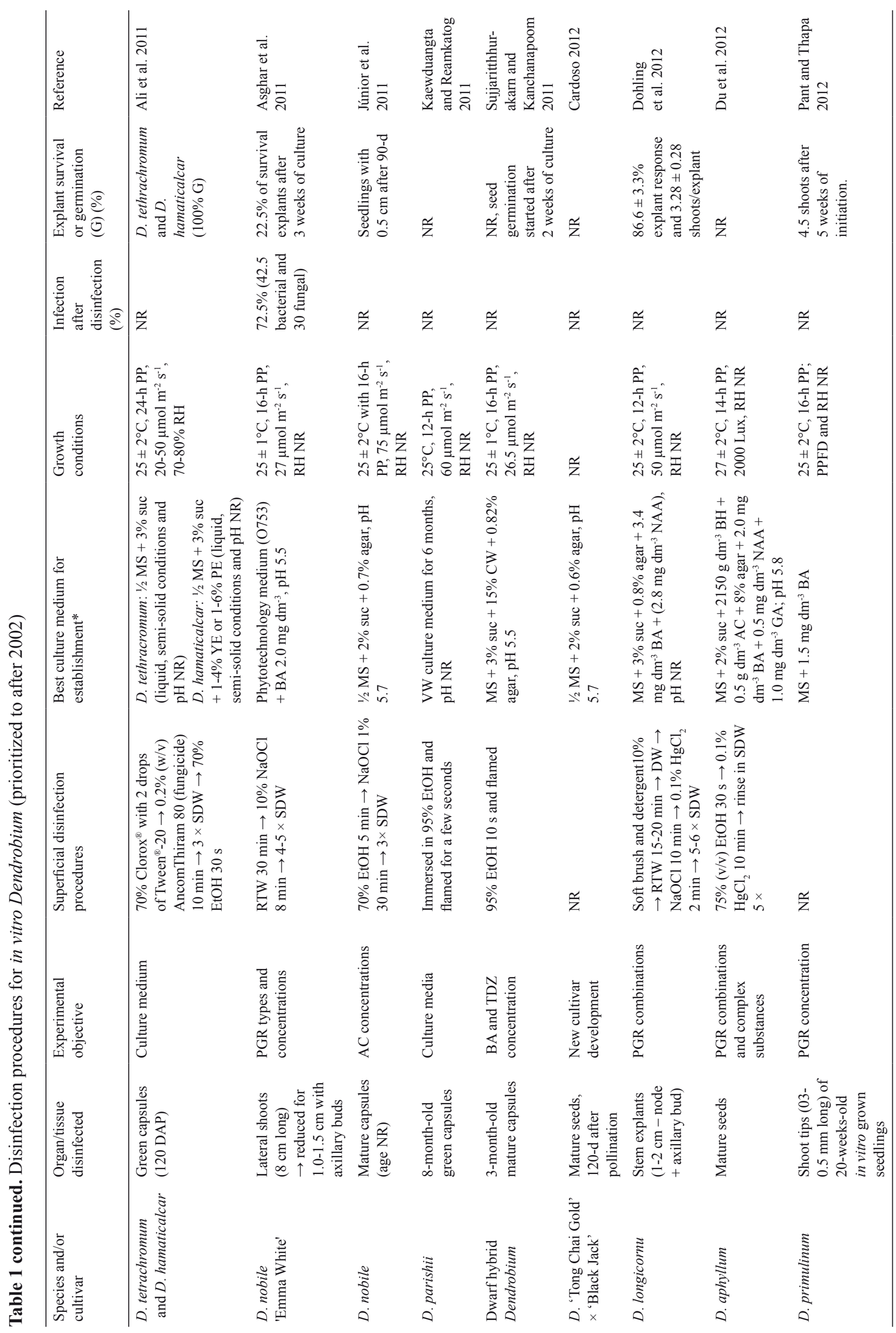




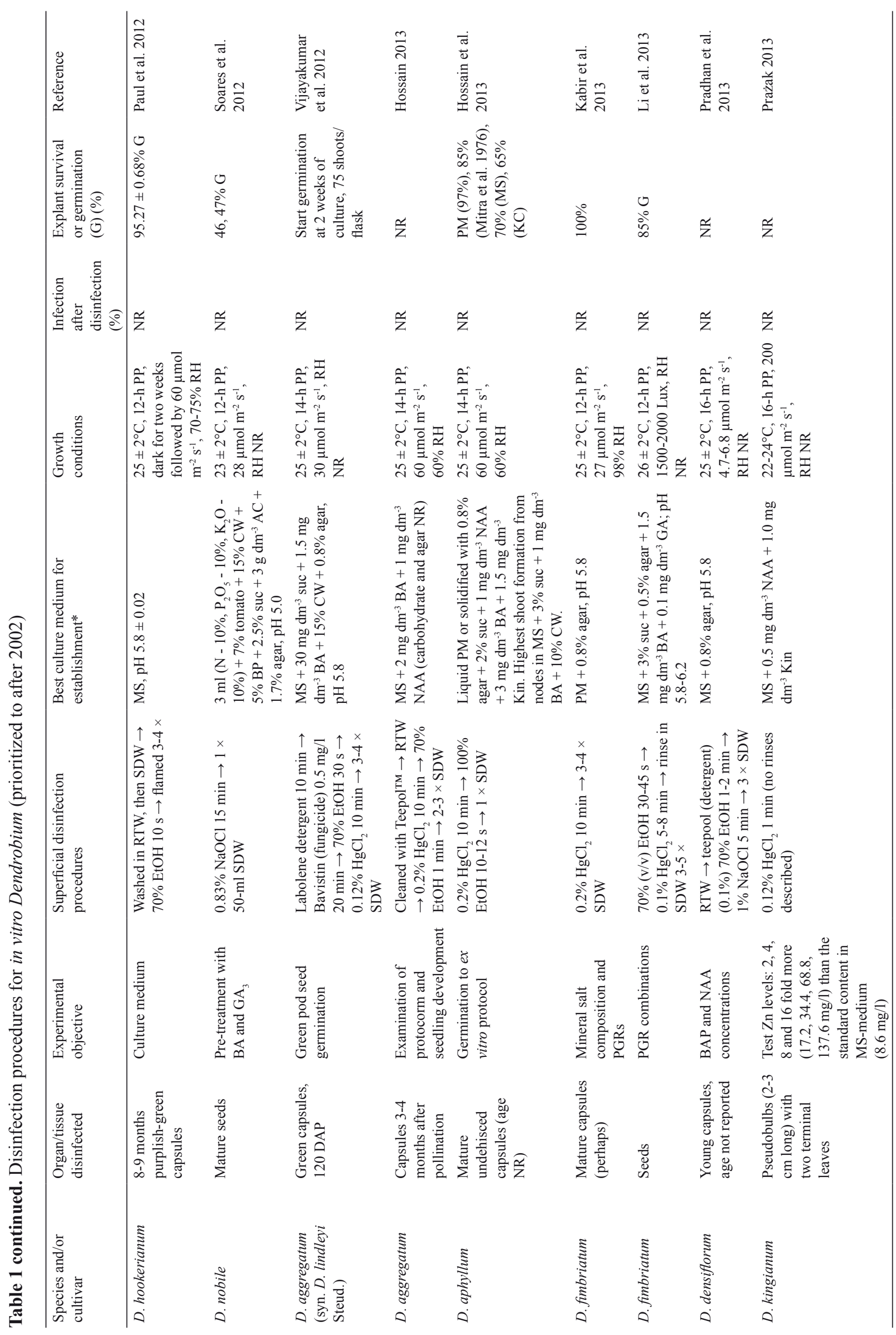




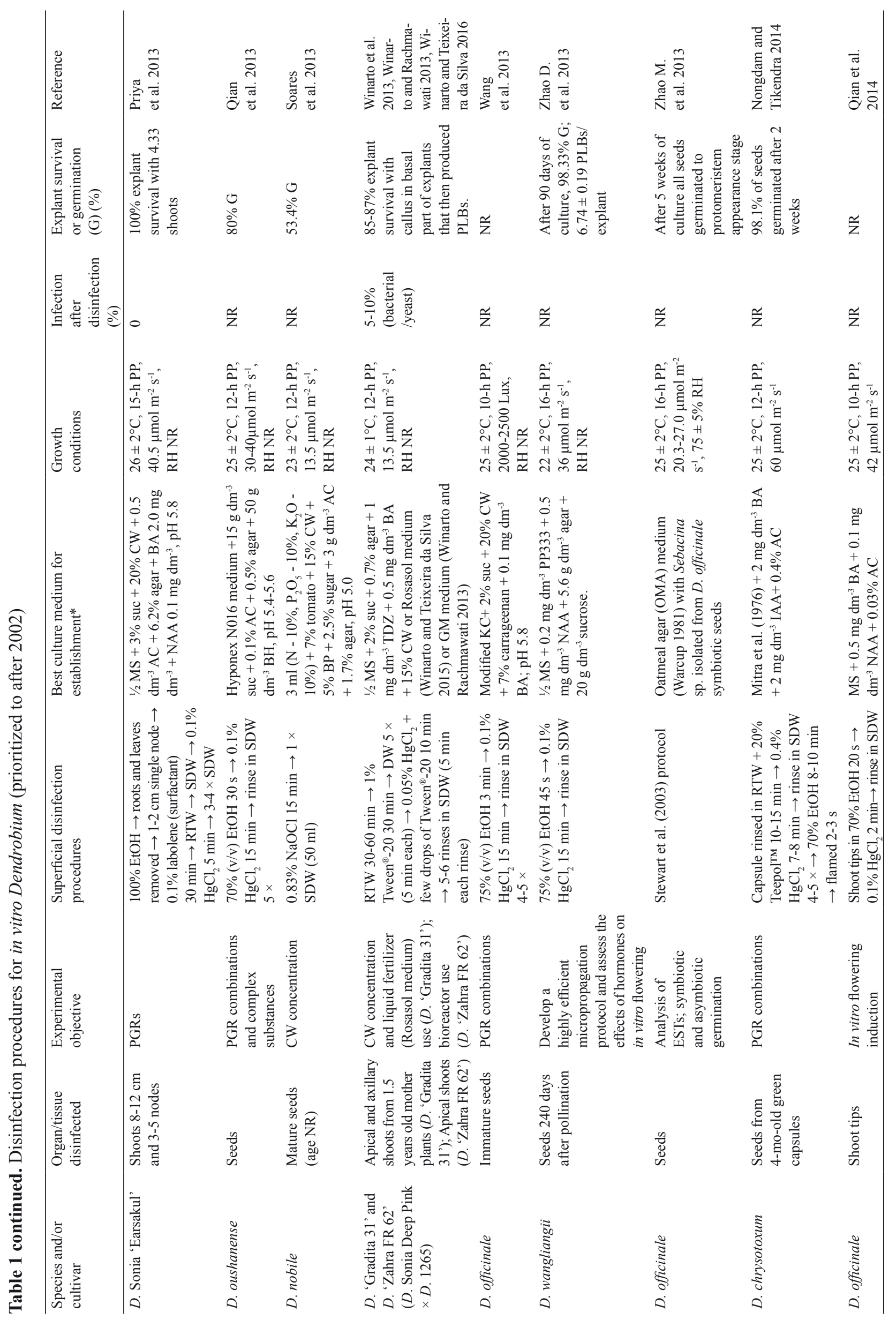




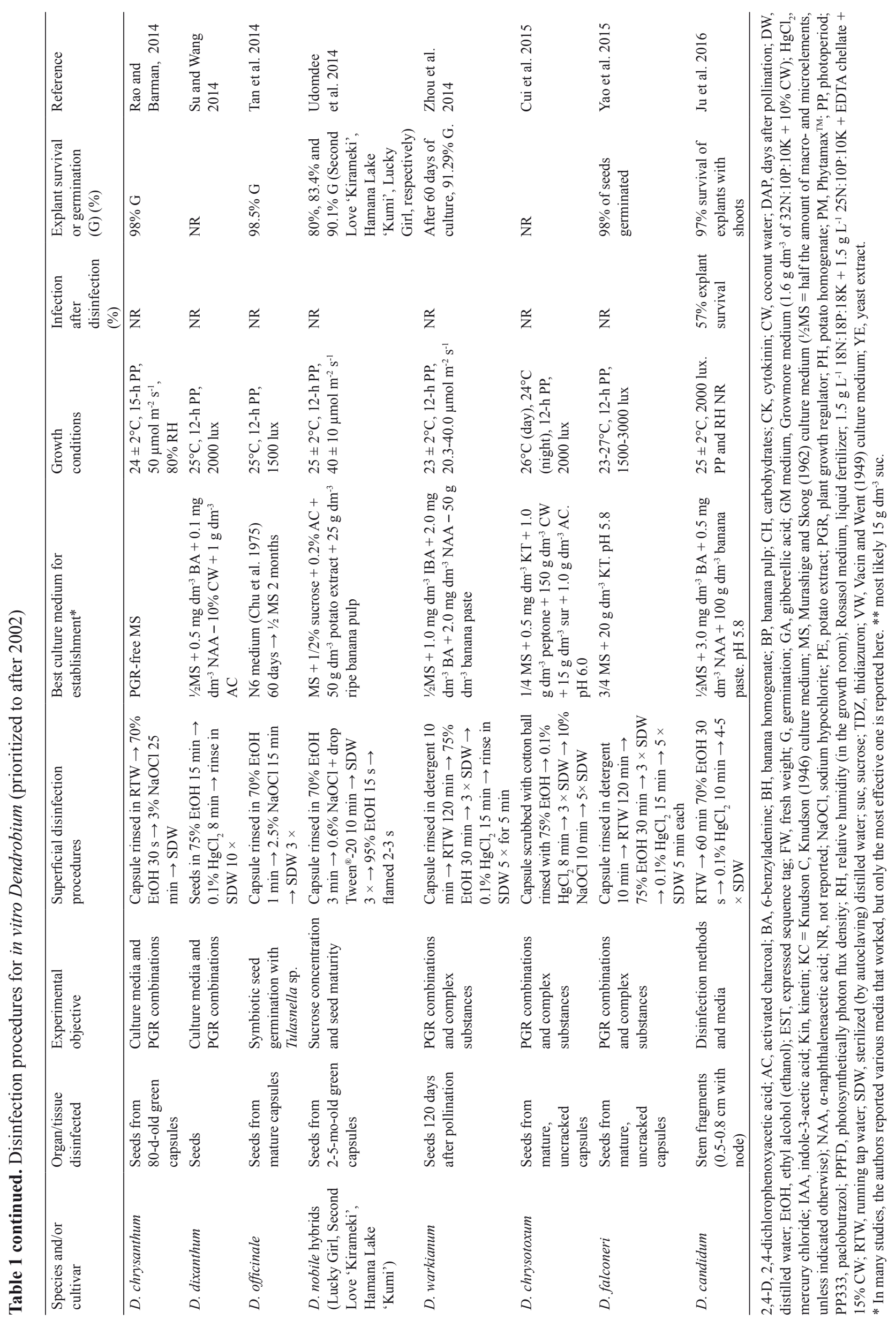



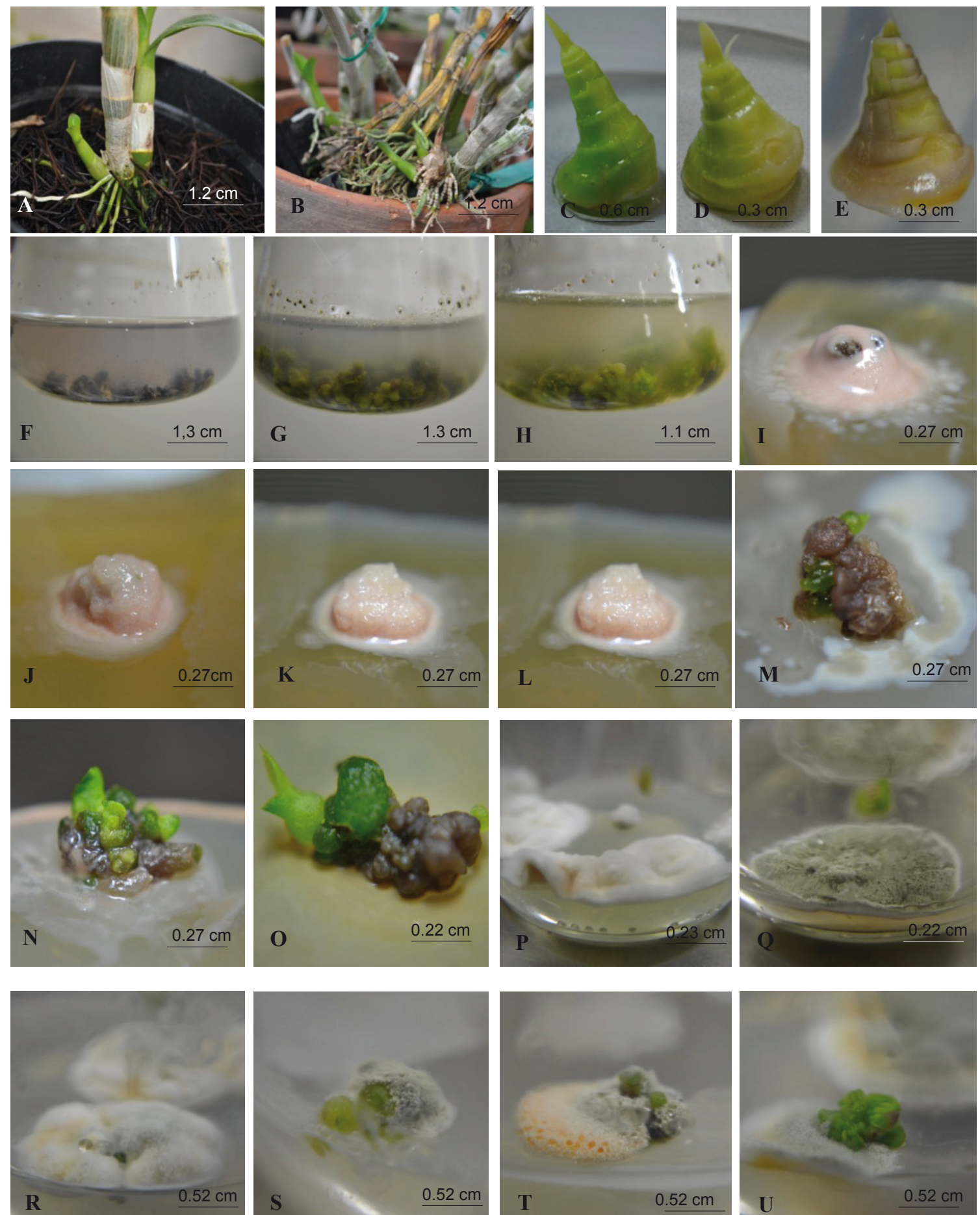

Figure 1. Several conditions affect and/or occur in Dendrobium tissue culture. First, the importance of age and the condition of donor plant material as an explant source for disinfection experiments and subsequent success of in vitro culture. (A) Optimal two-year-old donor plants maintained in the greenhouse under careful growth conditions result in highly regenerative shoot tip explants in in vitro culture (photo/data not shown); (B) in contrast to (A), 5-year-old donor plants maintained in the greenhouse with minimal care only provide explants with low or moderate regenerative capacity in in vitro culture (photo/data not shown). Second, the disinfection protocol can have a profound effect on the quality of the explant, as exemplified by Dendrobium 'Gradita 31' shoot tips. (C) Explant disinfected with running tap water (RTW) for $1.5 \mathrm{~h}, 1 \%$ liquid soap solution for $30 \mathrm{~min}, 1 \%$ pesticide for $30 \mathrm{~min}$ then $0.05 \%$ for $10 \mathrm{~min}$, and finally 6 rinses with sterile distilled water (SDW) result in light or no tissue damage, low contamination $(<15 \%)$ and reduced explant browning ( $<10 \%$ of explant). (D) Explant disinfected with RTW for $1.5 \mathrm{~h}, 1 \%$ liquid soap solution for $30 \mathrm{~min}, 1 \%$ pesticide for $30 \mathrm{~min}, 10 \%$ Clorox $^{\circledR}$ for 5 min then $5 \%$ Clorox $^{\circledR}$ for $10 \mathrm{~min}$, and finally 6 rinses with SDW result in more tissue damage, a higher percentage contamination (as much as 75\%) with 20-35\% explant browning. (continued on next page) 
Figure 1 continued description

(E) Explant disinfected with RTW for $1.5 \mathrm{~h}, 1 \%$ liquid soap solution for $30 \mathrm{~min}, 1 \%$ pesticide for $30 \mathrm{~min}, 20 \%$ Clorox $^{\circledR}$ for 5 min then $10 \%$ Clorox $^{\circledR}$ for $10 \mathrm{~min}$, and finally 6 rinses with SDW result in considerable tissue damage, low contamination $(<20 \%)$ but extensive browning $(75-80 \%)$ causing all explants to die. Third, Dendrobium liquid cultures 1.5 months after culture initiation can be easily contaminated if incomplete disinfection of shoot tip explants is not performed. (F) Contaminated Dendrobium 'Zahra FR 62' shoot tips by bacteria. (G) Contaminated D. 'Gradita 31' proliferated PLBs by bacteria. $(\mathrm{H})$ Contaminated $D$. 'Jayakarta' proliferated PLBs by bacteria in liquid half-strength MS medium containing $0.3 \mathrm{mg} \mathrm{dm}^{-3} \mathrm{TDZ}$ and $0.1 \mathrm{mg} \mathrm{dm}^{-3} \mathrm{NAA}$. For all cultivars, small shoots $( \pm 0.3 \mathrm{~cm}$ long $) \mathrm{served}$ as the donor explants and cultures were incubated in conditions described in Tab. 1 until PLB initiation was clearly observed. For all cultivars, explants were subcultured every 15 days and after PLB initiation then transferred to liquid half-strength MS supplemented with $0.3 \mathrm{mg} \mathrm{dm}^{-3} \mathrm{TDZ}$ and $0.1 \mathrm{mg} \mathrm{dm}^{-3} \mathrm{NAA}$. In this medium, periodic subcultures (4-5 times, each subculture period was 15 days) were carried out in the same medium to proliferate PLBs. For more details, also see Teixeira da Silva et al. (2015a) and Teixeira da Silva and Winarto (2016). Fourth, bacterial (I-O) and fungal (P-U) contamination of Dendrobium 'Zahra FR 62' (I, J, L, M, O, R), D. 'Gradita 31' (K, N, P, S) and D. 'Jayakarta' (Q, T) in solid and semi-solid cultures of shoot tips (I-K) or PLBs (L-T) can take place 2 months (I-Q) or 1.5 months (R-T) after culture initiation on half-strength MS containing $0.3 \mathrm{mg} \mathrm{dm}^{-3} \mathrm{TDZ}$ and $0.1 \mathrm{mg} \mathrm{dm}^{-3}$ NAA. Precise characterization of bacterial and fungal strains was not performed. All photos unpublished (B. Winarto)

accelerated the development of new pseudobulbs. This procedure led to the development of vigorous and highly regenerative explants with low contamination in in vitro aseptic culture of ferns (Winarto and Teixeira da Silva 2012) and Dendrobium hybrids (Winarto et al. 2013, Winarto and Rachmawati 2013) without any additional disinfection steps. Using these donor plants, in vitro seed germination was possible and PLBs or protocorms formed. The growth conditions of mother plants most likely represent the first and most important risk of contamination. Disinfection needs to be strong and complex when tissues of mother plant are old. While milder disinfection can theoretically result in higher regeneration since less tissue is damaged, stronger disinfection might result in lower regeneration due to greater explant damage by physical and chemical abrasion (Mng'omba et al. 2012), although no such studies that examine these links exist for Dendrobium. There are also no quantitative studies that examine the relation between the age of the explant tissue, or the age of the mother plant, and the level of contamination. Separately, the correlation between the age of the mother plant and regeneration efficiency has been reported in other species in which juvenile tissues generally resulted in better regeneration than tissues from adult mother plants or were less recalcitrant to regeneration (Liu and Pijut 2008, Cardoso and Habermann 2014, Lema-Rumińska and Kulus 2014). In addition, we observed that in most Dendrobium micropropagation studies that employed somatic tissues as explants, young shoots ( 0.5 to $12 \mathrm{~cm}$ long) were the main explant used rather than mature shoots with leaves or pseudobulbs (Tab. 1).
In general, contamination of explants from seeds, collected from immature or mature healthy capsules, is very low $(0-10 \%)$, probably because of the small size of seeds (Kauth et al. 2008). This, combined with highly sanitary conditions of fruit inside (due to a lack of endosperm) results in only a small amount of microorganisms which allows for simple and effective disinfection of explants derived from such tissues (as opposed to, for example, mature leaves). Jean Carlos Cardoso used, for seeds, $10 \mathrm{~min}$ disinfection in $10 \% \mathrm{NaOCl}(=0.20-0.25 \%$ of active chlorine) under agitation followed by two washes in autoclaved distilled water for seeds from different crossings among different Dendrobium species without contamination problems. Differently, explants from somatic tissues such as shoot tips normally have a greater chance of contamination, either by bacteria, yeast, or fungi hence the milky nature of the solution (Fig. 1I-U). It is likely that the use of long shoots $(5-8 \mathrm{~cm})$ that have been exposed to irrigation over the plant (sprinkling or similar) results in the accumulation of free-water in the portion between the sheath and the stem tissues, where the shoot tips and axillary shoots may be found (Fig. 1C-E), resulting in bacterial growth and thus easy contamination of tissues. For example, a plant that is watered from the top, thus wetting leaves, is likely to become more contaminated than one that is watered with a drip approach (Jean Carlos Cardoso, personal observations).

\section{CHOICE OF METHODS FOR SURFACE DISINFECTION}

Most papers used seeds from mature or immature capsules and young axillary shoots for initiating Dendrobium in vitro cultures (Tab. 1). As for many 
other plant species, the most common products for disinfection are based on chlorine-derived commercial solutions, such as $\mathrm{NaOCl}$ or mercury (II) chloride $\left(\mathrm{HgCl}_{2}\right)$ (Tab. 1).

A meta-analysis (Tab. 2) indicates that most (94.3\%) Dendrobium experiments describe a protocol for surface disinfection, but $92.5 \%$ of studies fail to report the percentage contamination while only $50.9 \%$ of studies indicate the percentage germination or explant regeneration (Tab. 1). One possible explanation is because most papers (estimated from Tab. 1 at in excess of 90\%) used an establishment phase only to obtain in vitro explants for the next step and to conduct the real experiment, without reporting the role of contamination and/or the regeneration efficiency of the aseptic technique(s) used. Another hypothesis is that contamination is not a problem in Dendrobium species, especially when seeds are used to initiate the in vitro culture. In support of this hypothesis, in $18.9 \%$ of studies, authors disinfected immature (or green) fruits (Tab. 1), before natural dehiscence, in which case the seeds are naturally "disinfected" (or rather, they are not naturally contaminated) inside the fruits, reducing the risk of contamination during in vitro culture. The use of green pod culture also prevents direct contact of seeds with the chemical disinfectant, which is potentially toxic to tissues (Yeoman and Macleod 1977, George 1993), thus improving the chance (and thus number) of seeds that are able to germinate. Soares et al. (2012) disinfected fruits before seed inoculation in vitro, and observed higher percentage germination $(80-100 \%)$ than when seeds were excised from fruits and then disinfected, obtaining only $46.47 \%$ germination (Tab. 1).

Observing the issue of disinfection from a different angle, somatic tissues tend to be more susceptible to contamination than seeds and to the toxic effects of chemical disinfectants (Yeoman and Macleod 1977, George 1993, Traore at el. 2005, George and Debergh 2008, Jan et al. 2013). A single use of $\mathrm{NaOCl}$ seemed to be the least effective for the disinfection of Dendrobium shoots but various combinations of different disinfectants (EtOH, $\mathrm{NaOCl}, \mathrm{HgCl}_{2}$ ) increased the efficacy of the disinfection procedure (Tab. 2). Contamination of shoot tips ranged from 0 to $100 \%$, using Clorox $^{\circledR}$ and Teepol $^{\mathrm{TM}}$ (time of exposure and concentration not reported by the authors) depended on the species: D. laxiflorum $(0 \%), D$. pseudoconantum $(0 \%), D$. canaliculatum (100\%), D. strebloceras (40-50\%), D. sp. Maluku

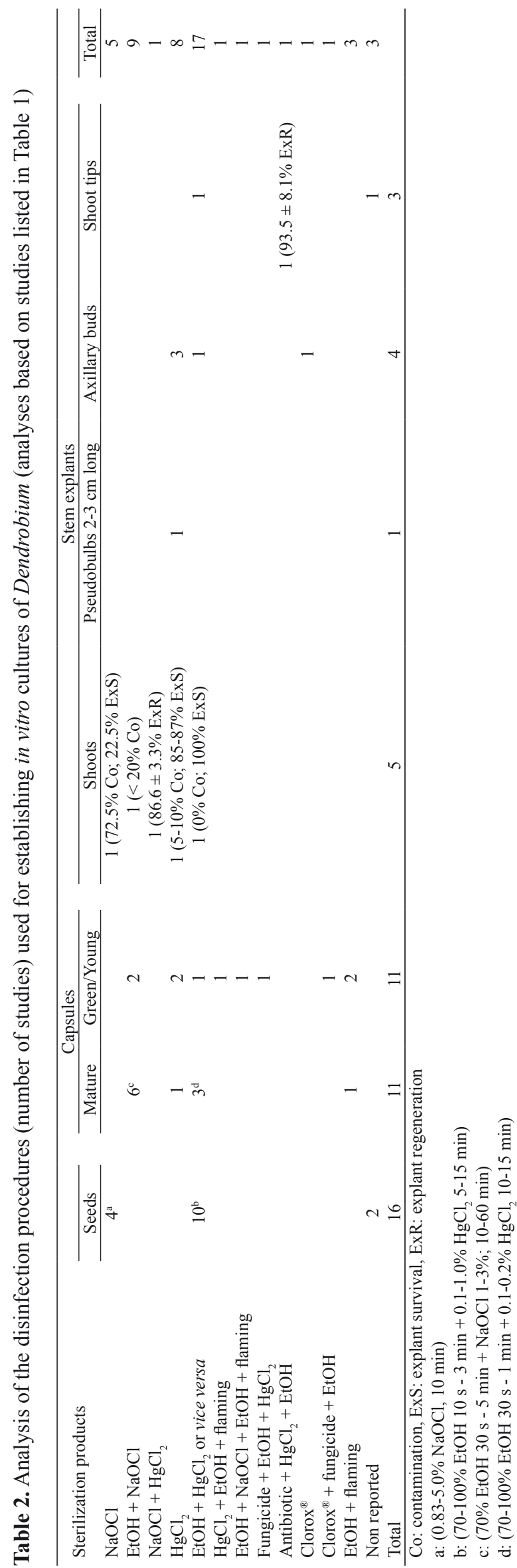


(100\%), D. lineale $(50 \%), D$. veratrifolium $(0-50 \%)$ or D. racianum ( $0 \%$ ) (Soetopo and Purnamaningsih 2012). In another study with $D$. nobile var. 'Emma white', Asghar et al. (2011) tested three different periods of explant surface disinfection $(6,8$ and $10 \mathrm{~min}$ ) with $10 \% \mathrm{NaOCl}$ followed by $4-5$ washes in sterilized (autoclaved) distilled water (SDW) and observed 0 to $12.5 \%$ necrosis and contamination ranging from 67.5 (35\% bacterial and $32.5 \%$ fungal) to $87.5 \%$ ( $47.5 \%$ bacterial and $40 \%$ fungal) and survival ranging from $12.5 \%$ (6 min) to $22.5 \%$ ( $8 \mathrm{~min}$ ). The latter condition, i.e., $8 \mathrm{~min}$, was the optimal disinfection period with the highest survival $(22.5 \%)$ with decreased infection (from $87.5 \%$ to $72.5 \%$ ) and with negligible necrosis (5\%), indicating the importance of finding the right balance between disinfection and explant survival during a disinfection procedure.

Based on the experience of Jean Carlos Cardoso, working with 10 Dendrobium hybrids (Denphal type), namely $D$. 'Brazilian Fire 101' (yellow with red strips), $D$. 'Wooleng' (white with purple lip), $D$. 'Tongchai Gold' (yellow with red lip), D. Red Prince (red), D. 'Visa Peach' (white and rosy), $D$. 'Sonia' (white and pink), among others, in a commercial lab (thanks to Uniplant Co., Brazil), at least $15-20 \%$ of axillary buds and shoot tips were contaminated by bacteria and/or yeast if the following protocol (unpublished) was used for surface disinfection: $70 \%$ alcohol for $1 \mathrm{~min}$, then $\mathrm{NaOCl}(0.5-0.6 \%$ of active chlorine) with 4-5 drops of Tween ${ }^{\circledR} 20 / 100 \mathrm{ml}$ for $20 \mathrm{~min}$ followed by three rinses in sterile distilled water. Using that protocol, $15-20 \%$ of the infected explants would result in a lethal response, i.e., explant death (caused by $100 \%$ contamination of those explants) while the remaining uncontaminated (80-85\%) explants could regenerate, although the regeneration potential was linked to the level of explant browning, a phenomenon that was also observed for $D$. crumenatum (Kaewubon et al. 2015). In the above protocol, intermediate washes with sterile distilled water were not performed, and in fact only eight studies listed in Table 1 provided an intermediary wash of each disinfectant before applying the next one even though a wash is generally not required between disinfectants, only in the final step. The need for independent washes of each steriliant is a topic that has not yet been explored in plant science and may be required for different species or genotypes. The efficiency of a disinfection procedure was tested by Ferreira et al. (2006) using 96\% ethanol for 2 min followed by different concentrations of $\mathrm{NaOCl}(20,40$ and $60 \%$, $\mathrm{v} / \mathrm{v}$ ) for $30 \mathrm{~min}$ for surface disinfection of $8-\mathrm{cm}$ lateral shoots of $D$. 'Second Love' (Nobile type). They observed that $40 \%$ commercial bleach $(2.5 \%$ active chlorine) followed by three washes in SDW resulted in a high level (80\%) of decontaminated material with no visible deleterious effects. This is considered, in commercial terms, to be a good result, and could be used for other species or genotypes to test the efficiency of the protocol. When $\mathrm{HgCl}_{2}$ was used as a substitute for, or in addition to, $\mathrm{NaOCl}$ treatment for the surface disinfection of shoots, good regeneration results were obtained, as observed in D. nobile $(93.5 \pm 8.1 \%$ of responsive explants) (Malabadi et al. 2005), D. longicornu $(86.6 \pm 3.3 \%$ explant response) (Dohling et al. 2012) and $D$. Sonia 'Earsakul' (100\% explant survival) (Kumari et al. 2013). $\mathrm{HgCl}_{2}$ was also the chosen disinfection agent for $D$. dixanthum seeds (Su and Wang 2014), D. warkianum seeds (Zhou et al. 2014), and D. chrysotoxum seeds (Ju et al. 2016).

Different explants require different types of compounds, concentrations and exposure periods for the disinfection process to be optimized. For capsules, the most commonly used surface disinfection protocol applied $70 \%$ ethanol for $30 \mathrm{sec}$ to $5 \mathrm{~min}$, followed by $1-3 \% \mathrm{NaOCl}$ for $20-$ $60 \mathrm{~min}\left(15.1 \%\right.$ of papers), or with $0.1-1.0 \% \mathrm{HgCl}_{2}$ (substituting $\mathrm{NaOCl}$ ) for $5-15 \mathrm{~min}$ ( $7.5 \%$ of papers) and obtained more than $80 \%$ germination, but in all cases failed to describe the percentage contamination (Tab. 1). Similar treatments were used for seeds and lateral shoots (Tab. 1). However, some authors $(16.7 \%)$ dipped undehisced capsules in 70 or $95 \%$ ethanol and flamed capsules for surface disinfection (Sujjaritthurakarn and Kanchanapoom 2011, Paul et al. 2012). Paul et al. (2012) used this technique for D. hookerianum capsules and observed 95.27 $\pm 0.68 \%$ seed germination. Most authors did not describe the efficiency of disinfection procedures because that was not the main objective of their experiment.

\section{CONCLUSIONS, LIMITATIONS AND FUTURE PERSPECTIVES}

Use of in vitro symbiotic germination is another way to improve Dendrobium micropropagation (Teixeira da Silva et al. 2015c) but the introduction of symbionts poses a significant challenge to the in vitro culture of orchids because the balance between the need for the symbiont and the need to maintain a sterile culture, i.e., without the symbiont 
growing excessively and killing the plant tissues as a result of exposure to a nutrient-rich environment, is a tremendous challenge in orchid biotechnology. For example, Zhao et al. (2013) observed improved (almost 100\%) seed germination by co-cultivation of a fungus Sebacina sp. with D. officinale seeds after five weeks of culture while the same culture medium (oatmeal agar) without fungus resulted in no seed germination.

Optimal timing for harvesting explants and the age and physiological state of donor plants are important aspects that can increase the efficiency of surface disinfection of the explants and ensuing success of in vitro culture (Fig. 1A) (Hall 1999), including seed germination, callus and/or PLB formation. Plant material derived from plants grown in suboptimal conditions, for example aged material or in a poor physiological state, are more sensitive to disinfectants than explant from plants grown in optimal in vivo conditions, while the size of the explant (e.g., thin cell layers; Teixeira da Silva 2013, Teixeira da Silva and Dobránszki 2013) can make explants more sensitive to disinfectants due to their small size, while sub-optimal harvesting period or season may also contribute to a high level of contamination (Traore et al. 2005, George and Debergh 2008, Dobránszki and Teixeira da Silva 2010, Mihaljevic et al. 2013). For example, $100 \%$ germination of D. tetrachromum and D. hamaticalcar was observed when green capsules 120 days after pollination were used (Ali et al. 2011). In most studies reported in the literature, the level of explant contamination has rarely been reported during the establishment of an aseptic culture. The disinfection protocol of explants can affect the quality and thus vitality of the explant (Fig. 1C-E) and hence the success and outcome of the in vitro protocol in liquid (Fig. 1F-H), semisolid or solid medium (Fig. 1I-U). The lack of such details in almost all studies $>90 \%$ of the papers did not report the level of explant contamination or survival; Tab. 2) reported in the literature (Tab. 1) is problematic since such information could assist future researchers by eliminating protocols that would not result in optimal explant decontamination. Other important aspects that should be included in future experiments (and research papers) that disinfect ex vitro plant material are: 1) the types of contaminants found, e.g., specific yeast, bacteria and fungi; (2) pretreatment of donor plants in the field or greenhouse, including fertilizers, watering, plant maintenance, pest and weed control, that could induce or create highly regenerative explant sources by improving its physiological state, decreasing the level of surface contamination, or both; (3) new emerging disinfectants as possible tissue culture sterilants such as chlorine dioxide $\left(\mathrm{ClO}_{2}\right)$ (Cardoso and Teixeira da Silva 2012), iodine and/or potassium iodide (Deein et al. 2013), or peracetic acid (Unemoto et al. 2009), all of which can be used in plant tissue culture (e.g., see use for chrysanthemums; Teixeira da Silva and Kulus 2014). At least one study that addresses such issues, including addressing the weaknesses and failures in the literature thus far, for a range of Dendrobium genotypes, is required. Such information will undoubtedly further improve the success of the next step, in vitro culture.

A well-established disinfection procedure assists in obtaining suitable explants for regeneration and germination studies (e.g., Fig. 2). However, some endogenous bacteria or yeast could be a problem for orchid propagation and common chemical products used for the disinfection of the tissue surface does not always result in explants free of microorganisms. It is common to observe some persistent yeast and/or bacterial strains that contaminate the explants of orchids cultivated in vitro, especially those derived from somatic tissues. In other orchid species, similar microorganisms were observed, such as in Habenaria radiata, in which $33 \%$ of explants from shoot apices were contaminated with bacteria (Mitsukuri et al. 2009). Brown et al. (1982), who tested different fungicides and antibiotics to prevent contamination in several orchid species, observed that only one flask from a treatment that combined a cocktail (benomyl, quintozene, penicillin $\mathrm{G}$, amphotericin $\mathrm{B}$ and sodium omadine) resulted in uncontaminated seeds and zygotic embryos of Dendrobium specisum var. hillii. Virus infection is another problem in orchids (Khentry et al. 2006b) and the elimination of important viruses such as Cymbidium mosaic virus (CymMV) and Odontoglossum ringspot virus (ORSV) is possible by seedling culture (Khentry et al. 2006b), thin section culture (Lim et al. 1993) and PLB culture (Chanprame et al. 2011) combined or not with chemotherapy using ribavirin treatment. For example, Khentry et al. (2006a) observed the occurrence of CymMV (but not ORSV) in six orchid genera, including in in vitro micropropagated plantlets of several Dendrobium cultivars ('Chanel', $D$. 'Chao Praya', $D$. 'Pravit White', $D$. 'Sakura' and $D$. 'Shawin White'), which displayed high rates of infection. Khentry et al. (2006a) observed, in 14 Dendrobium cut flowers propagated by cuttings, 


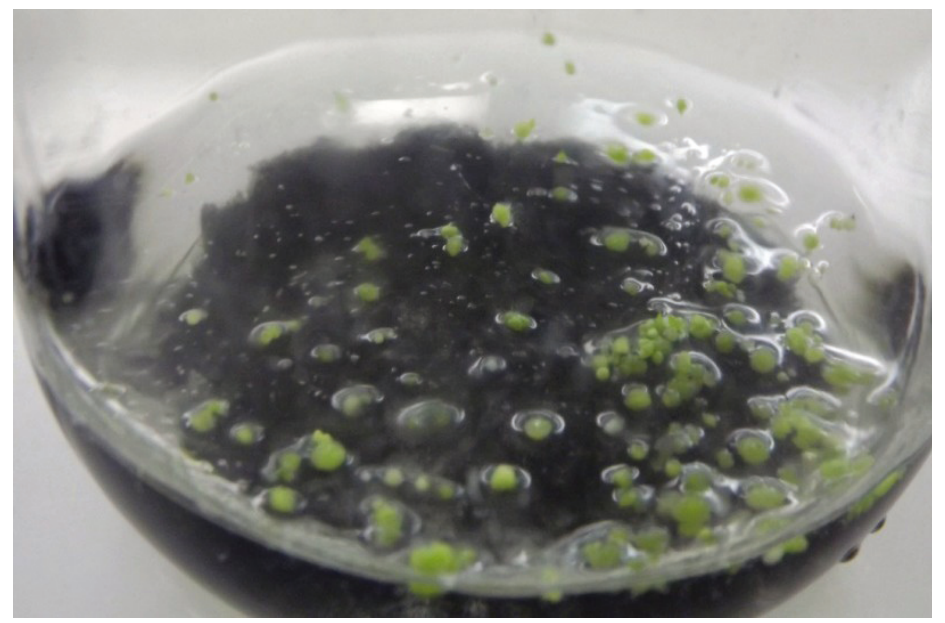

Figure 2. Germinated seed of Dendrobium 'Brazilian Fire 101' $\times$ D. 'Black Jack' $30 \mathrm{~d}$ after in vitro inoculation of seeds in $1 / 2 \mathrm{MS}$ basal medium with $20 \mathrm{~g} \mathrm{dm}^{-3}$ sucrose, $1.5 \mathrm{~g} \mathrm{dm}^{-3}$ activated charcoal and $2.4 \mathrm{~g} \mathrm{dm}^{-3}$ Gelrite $^{\circledR}$ (pH 5.65-5.75). Mother/parent plants (2.5 years-old) were grown in plastic pots containing coconut chips as substrate, in a greenhouse $\left(15-28^{\circ} \mathrm{C}\right.$; minimum $50 \%$ relative humidity). Disinfection was successful with $10 \%$ bleach $(2.0-2.5 \%$ active chlorine) for $10 \mathrm{~min}$ and constant agitation followed by two rinses in sterile distilled water. Unpublished photo: Jean Carlos Cardoso

that the rate of infection by $\mathrm{CymMV}$ ranged from $25-100 \%$ with a mean of $65.8 \%$ of samples infected, and in 29 cultivars propagated by tissue culture, a range of 0 to $100 \%$ of plantlets were infected, depending on the cultivar, with a mean of $18.6 \%$ of all samples infected. CymMV was also detected in PLBs of Dendrobium 'Sonia' obtained from tissue culture laboratories in Thailand using RT-PCR (in 78\% of samples) and ELISA (in 22\% of samples), showing that RT-PCR was more sensitive at detecting systemic viruses in orchids (Khentry et al. 2007). The use of multiplex RTPCR could be used for simultaneous detection of CymMV, ORSV and Orchid fleck virus (OFV) in Dendrobium and another orchid genus (Ali et al. 2014, Kim and Choi 2015). Using meristem (0.1 to $1 \mathrm{~mm}$ ) culture of Mokara Char Kuan 'Pink', Lim et al. (1993) observed that regenerated plantlets from the culture of larger meristems remained infected by CymMV and ORSV while TLCs of infected plantlets and PLBs, when treated with ribavirin, were free of these viruses. Interestingly, few papers described or show advances in studies of these microorganisms, although contamination problems continue to be observed in commercial laboratories and commercial orchid nurseries (Khentry et al. 2006a, 2006b, 2007; Fig. 1A, B, I-U).

\section{FUNDING}

The authors did not receive funding for this research.

\section{AUTHOR CONTRIBUTIONS}

All authors contributed to all aspects of this manuscript, including development of the ideas, writing, revisions and joint responsibility for the content.

\section{CONFLICT OF INTEREST}

Authors declare no conflict of interest.

\section{REFERENCES}

Alam M.K., Rashid M.H., Hossain M.S., Salam M.A., Rouf M.A., 2002. In vitro seed propagation of dendrobium (Dendrobium transparens) orchids as influenced by different media. Biotechnology 1(2-4): 111-115.

Ali M.J., Murdad R., Latip M.A., 2011. In vitro seed germination of Bornean endemic orchids Dendrobium tetrachromum and Dendrobium hamaticalcar. In: Empower. Sci. Tech. Innov: Towards Better Tomorrow, UMTAS: 770-778.

Ali R.N., Dann A.L., Cross P.A., Wilson C.R., 2014. Multiplex RT-PCR detection of three common viruses infecting orchids. Arch. Virol. 159: 3095 3099.

Asghar S., Ahmad T., Hafiz I.A., Yaseen M., 2011. In vitro propagation of orchid (Dendrobium nobile) var. Emma White. Afr. J. Biotechnol. 10 (16): 3097-3103.

Bhadra S.K., Barua A.K., Bhattacharjee B., Hossain M.M., 2002. In vitro micropropagation of Dendrobium aphyllum (Roxb.) G. E. C. Fisher. Bangladesh J. Genet. Biotechnol. 3: 47-50.

Brown D.M., Groom C.L., Cvitanik M., Brown M., Cooper J.L., Arditti J., 1982. Effects of fungicides 
and bactericides on orchid seed germination and shoot tip cultures in vitro. Plant Cell Tiss. Org. Cult. 1: $165-180$.

Cardoso J.C., 2012. Dendrobium 'Brazilian Fire 101' New option of color of flowers for the ochid market. Hortic. Bras. 30: 561-564.

Cardoso J.C., Habermann G., 2014. Adventitious shoot induction from leaf segments in Anthurium andraeanum is affected by age of explants, leaf orientation and plant growth regulator. Hortic. Env. Biotech. 55: 56-62.

Cardoso J.C., Teixeira da Silva J.A., 2012. Micropropagation of gerbera using chlorine dioxide $\left(\mathrm{ClO}_{2}\right)$ to sterilize the culture medium. In Vitro Cell. Dev. Biol. - Plant 48: 362-368.

Chanprame S., Hongrrayoon R., Limsanguan P., 2011. Elimination of Cymbidium mosaic virus from Dendrobium orchid PLB by chemotherapy. J. Int. Soc. Southeast Asian Agric. Sci. 17: 1636-1648.

Chu C.C., Wang C.C., Sun C.S., Hsu C., Yin K.C., Chu C.Y., Bi F.Y., 1975. Establishment of an efficient medium for anther culture of rice through comparative experiments on the nitrogen sources. Sci. Sin. 18: 659-668.

Cui B., Kang Y.Y., Wang J.Q., Jiang S.H., Liang F., LiU J., 2015. Research on the tissue culture and rapid propagation technology of Dendrobium chrysotoxum Lindl. Chin. Agri. Sci. Bull. 31(19): 111-121 (in Chinese with English abstract).

Das A.K., Das J., Gogoi H.K., Srivastava R.B., 2008. Mass propagation of orchids through in vitro seed culture technology. J. Cell Tiss. Res. 8(2): 1585-1588.

De Moraes L.M., Cavalcante L.C.D., Faria R.T., 2002. Substratos para aclimatização de plântulas de Dendrobium nobile Lindl. (Orchidaceae) propagadas in vitro. Acta Scient. 24: 1397-1400 (in Portuguese with English abstract).

Deein W., Thepsithar C., Thongrukdee A., Tippornwong S., 2013. Growth of chrysanthemum explants on MS medium sterilized by disinfectants and essential oils. Int. J. Biosc. Biochem. Bioinform. 3(6): 609-613.

Dobránszki J., Teixeira dA Silva J.A., 2010. Micropropagation of apple - a review. Biotech. Adv. 28: 462-488.

Dohling S., Kumaria S., Tandon P., 2012. Multiple shoot induction from axillary bud cultures of the medicinal orchid, Dendrobium longicornu. AoB Plants 2012: pls032.

Du G., Lai T.C., Yang H.Y., 2012. Study on the tissue culture of Dendrobium aphyllum (Roxb) C. E. C. Fisch. North Hortic. 8: 140-141.

Dutta S., Chowdhury A., Bhattacharjee B., Nath P.K., DutTA B.K., 2011. In vitro multiplication and protocorm development of Dendrobium aphyllum (Roxb.) CEC Fisher. Assam Univ. J. Sci. Technol: Biol. Env. Sci. 7(1): 57-62.

Ferreira W.M., Kerbauy G.B., Costa A.P.P., 2006. Micropropagation and genetic stability of a Dendrobium hybrid (Orchidaceae). In Vitro Cell. Dev. Biol. - Plant 42: 568-571.

Gamborg O.L., Miller R.A., Ojima K., 1968. Nutrient requirements of suspension cultures of soybean root cells. Exp. Cell Res. 50: 151-158.

George E.F., 1993. Plant Propagation by Tissue Culture. Part 1, Technology, Exegetics Ltd., England: 121-145.

George E.F., Debergh P.C., 2008. Micropropagation: Uses and Methods. In: Plant Propagation by Tissue Culture, The Background. Vol.1. E.F. George, M.A. Hall and G-J. De Klerk (eds), Springer, Dordrecht, The Netherlands: 29-64.

Hajong S., Kumaria S., Tandon P., 2010. In vitro propagation of the medicinal orchid Dendrobium chrysanthum. Proc. Indian Natl. Sci. Acad. 76(1): 1-6.

Hall R.D., 1999. An introduction to plant-cell culture. In: Plant Cell Culture Protocols. R.D. Hall. (ed.), Humana Press Inc., Totowa, New Jersey: 1-18.

Hossain M.M., 2013. In vitro embryo morphogenesis and micropropagation of Dendrobium aggregatum Roxb. Plant Tissue Cult. Biotech. 23(2): 241-249.

Hossain M.M., Sharma M., Pathak P., 2013. In vitro propagation of Dendrobium aphyllum (Orchidaceae) - seed germination to flowering. J. Plant Biochem. Biotechnol. 22: 157-167.

JAN A., Вhat K.M., Вhat S.J.A., Mir M.A., ВнаT M.A., WANi I.A., RAther J.A., 2013. Surface sterilization method for reducing microbial contamination of field grown strawberry explants intended for in vitro culture. Afr. J. Biotech. 12(39): 5749-5753.

Jin X.H., Chen S., Luo Y., 2009. Taxonomic revision of Dendrobium moniliforme complex (Orchidaceae). Sci. Hortic. 120: 143-145.

Ju S.M., Zhu W.L., Wang W.L., GaO Y., Ma T., 2016. Direct regeneration of seedling from stem fragments of Dendrobium candidum. J. Gansu Agric. Univ. 51(1): 45-48 (in Chinese with English abstract).

Júnior R.F.G., Neto P.C., Mantovani C., 2011. Crescimento in vitro de Dendrobium nobile Lindley com adição de carvão ativado. Científica 40: 28-34 (in Portuguese with English abstract).

Kabir M.F., Rahman M.S., Jamal A., Rahman M., Khalekuzzaman M., 2013. Multiple shoot regeneration in Dendrobium fimbriatum Hook an ornamental orchid. J. Animal Plant Sci. 23(4): 11401145.

Kaewduangta W., Reamkatog P., 2011. Effect of modification medium on growth development of Dendrobium parishii in vitro. American-Eurasian J. Agric. Environ. Sci. 11: 117-121.

Kaewubon P., Hutadilok-Towatana N., Teixeira da Silva J.A., Meesawat U., 2015. Ultrastructural and biochemical alterations during browning of Pigeon orchid (Dendrobium crumenatum Swartz) callus. Plant Cell Tiss. Org. Cult. 121(1): 53-69.

Kauth P.J., Dutra D., Johnson T.R., Stewart S.L., Kane M.E., Vendrame W., 2008. Techniques and 
applications of in vitro orchid seed germination. In: Floriculture, Ornamental and Plant Biotechnology: Advances and Topical Issues (Vol. V). J.A. Teixeira da Silva (ed.), Global Science Books, Isleworth, UK: 375-391.

Khentry Y., Chowpongpang S., Paradornuwat A., Tantiwiwat S., ThaveEchai N., 2006a. Incidence of Cymbidium mosaic virus and Odontoglossum ringspot virus in Dendrobium spp. in Thailand. Crop Protection 25: 926-932.

Khentry Y., Chowpongpang S., Paradornuwat A., Tantiwiwat S., Thaveechai N., 2007. Detection of Cymbidium mosaic virus in protocorm-like bodies in Dendrobium Sonia using one-step RT-PCR. J. Plant Biochem. Biotech. 16(2): 123-125.

Khentry Y., Paradornuwat A., Tantiwiwat S., Phansiri S., Thaveechai N., 2006b. Incidence of Cymbidium mosaic virus and Odontoglossum ringspot virus in in vitro Thai native orchid seedlings and cultivated orchid mericlones. Kasetsart J. (Nat. Sci.) 40: 49-57.

Kiм S.M., Chог S.H., 2015. Simultaneous detection of Cymbidium mosaic virus and Odontoglossum ringspot virus in orchids using multiplex RT-PCR. Virus Genes 51: 417-422.

KnUdson K., 1946. A new nutrient solution for germination of orchid seeds. Am. Orchid Soc. Bull. 15: 214-217.

Kong Q., YuAN S.Y., VÉGVÁRI G.Y., 2007. Micropropagation of an orchid Dendrobium strongylanthum Rchb.f. Int. J. Hortic. Sci. 13: 61-64.

Kumari P., Sabina George T., Rajmohan K., 2013. Influence of plant growth regulators on in vitro clonal propagation of Dendrobium Sonia 'Earsakul'. J. Biol. Innov. 2(2): 51-58.

Lema-Rumińska J., Kulus D., 2014. Micropropagation of cacti - a review. Haseltonia 19: 46-63.

Li C., Zhang Z.J., Wei Y., Li L.X., Ling Z.Z., Wei K.H., 2013. Study on tissue culture and rapid propagation of Dendrobium fimbriatum Hook. var. oculatum. Hook. North Hortic. 6: 105-107.

Lim S.T., Wong S.M., GoH C.J., 1993. Elimination of Cymbidium mosaic virus and Odontoglossum ringspot virus from orchids by meristem culture and thin section culture with chemotherapy. Ann. Appl. Biol. 122: 289-297.

Liu X., Pijut P.M., 2008. Plant regeneration from in vitro leaves of mature black cherry (Prunus serotina). Plant Cell Tiss. Org. Cult. 94: 113-123.

Lo S.F., Nalawade S.M., Kuo C.L., Chen C.L., Tsay H.S., 2004. Asymbiotic germination of immature seeds, plantlet development and ex vitro establishment of plants of Dendrobium tosaense Makino a medicinally important orchid. In Vitro Cell. Dev. Biol. - Plant 40: 528-535.

Lone A.B., Barbosa C.M., Faria R.T., TAKahashi L.S.A., Fonseca I.C.B., 2008. Seleção de genótipos de Dendrobium phalaenopsis (Orchidaceae) nas fases de propagação in vitro e aclimatização. Semina:
Ciências Agrárias 29: 755-760 (in Portuguese with English abstract).

Luo J.P., Wang Y., Zha X.Q., Huang L., 2008. Micropropagation of Dendrobium densiflorum Lindl. ex Wall. through protocorm-like bodies: effects of plant growth regulators and lanthanoids. Plant Cell Tiss. Org. Cult. 93: 333-340.

Luo J.P., Wawrosch C., Kopp B., 2009. Enhanced micropropagation of Dendrobium huoshanense C.Z. Tang et S.J. Cheng through protocorm-like bodies: The effects of cytokinins, carbohydrate sources and cold pretreatment. Sci. Hort. 123: 258-262.

Malabadi R.B., Mulgund G.S., Kallappa N., 2005. Micropropagation of Dendrobium nobile from shoot tip sections. J. Plant Physiol. 162: 473-478.

Maridass M., Mahesh R., Raju G., Benniamin A., Muthuchelian K., 2010. In vitro propagation of Dendrobium nanum through rhizome bud culture. Int. J. Biol. Technol. 1(2): 50-54.

Meesawat U., Kanchanapoom K., 2002. In vitro plant regeneration through embryogenesis and organogenesis from callus culture of pigeon orchid (Dendrobium crumenatum Sw.). Thammasat Int. J. Sci. Tech. 7(2): 9-17.

Mihaljevic I., Dugalic K., Tomas V., Viljevac M., Pranjic A., Cmelik Z., Puskar B., Jurkovic Z., 2013. In vitro sterilization procedures for micropropagation of ‘Oblacinska' sour cherry. J. Agric. Sci. 58(2): 117126.

Mitra G.C., Prasad R.N., Roychowdhary A., 1976. Inorganic salts and differentiation of protocorms in seed-callus of an orchid and correlated changes in its free amino acid content. Indian J. Exp. Biol. 14: 350-351.

Mitsukuri K., Arita T., Johkan M., Yamasaki S., Mishiba K-I., Oda M., 2009. Effects of type of explant and dark preconditioning on bud formation in Habenaria radiata (Thunb.) in vitro. HortScience 44(2): 523-525.

Mng'omba S.A., Sileshi G., Du Toit E.S., Akinnifesi F.K., 2012. Efficacy and utilization of fungicides and other antibiotics for aseptic plant cultures, fungicides for plant and animal diseases. In: Fungicides for Plant and Animal Diseases. D. Dhanasekaran (ed.), InTech, Croatia: 245-254.

Murashige T., Skoog F., 1962. A revised medium for rapid growth and bioassays with tobacco tissue cultures. Physiol. Plant. 15: 473-497.

Niedz R.P., Bausher M.G., 2002. Control of in vitro contamination of explants from greenhouse- and field-grown trees. In Vitro Cell. Dev. Biol. - Plant 38: 468-471.

Nitsch J.P., 1969. Experimental androgenesis in Nicotiana. Phytomorphology 19: 389-404.

Nongdam P., Tikendra L., 2014. Establishment of an efficient in vitro regeneration protocol for rapid and mass propagation of Dendrobium chrysotoxum 
Lindl. using seed culture. Scientific World J. 2014: Article ID 740150, 8 p.

Onwubiko N.C., Nkogho C.S., Anyanwu C.P., Onyeishi G.C., 2013. Effect of different concentration of sterilant and exposure time on sweet potato (Ipomoea batatas Lam) explants. Int. J. Curr. Microbiol. Appl. Sci. 2(8): 14-20.

Pant B., Thapa D., 2012. In vitro mass propagation of an epiphytic orchid, Dendrobium primulinum Lindl. through shoot tip culture. Afr. J. Biotechnol. 11(42): 9970-9974.

Paul S., Kumaria S., Tandon P., 2012. An effective nutrient medium for asymbiotic seed germination and large-scale in vitro regeneration of Dendrobium hookerianum, a threatened orchid of northeast India. AoB Plants 2012; plr032.

Pradhan S., Paudel Y.P., Pant B., 2013. Efficient regeneration of plants from shoot tip explants of Dendrobium densiflorum Lindl., a medicinal orchid. Afr. J. Biotech. 12: 1378-1383.

PrAŻAK R., 2013. The influence of zinc on growth and development of Dendrobium kingianum Bidwill in in vitro culture. Electronic J. Polish. Agric. Univ. 16(2), \#6. Available online at http://www.ejpau. media.pl/volume16/issue2/art-06.html; cited on 27 March 2016.

Priya Kumari I., Sabina George T., Rajmohan K., 2013. Influence of plant growth regulators on in vitro clonal propagation of Dendrobium Sonia 'Earsakul'.J. Biol. Innov. 2(2): 51-58.

Puchoos D., 2004. Comparison of different culture media for the in vitro culture of Dendrobium (Orchideaceae). Int. J. Agric. Biol. 6: 884-888.

Qian W.L., Zhang J.X., Wu K.L., Zeng S.J., Duan J., 2013. Study on propagation and cultivation technique of Dendrobium huoshanense seedlings. J. Trop. Subtrop. Bot. 21(3): 240-246.

Qian X., Wang C.X., Ouyang T., Tian M., 2014. In vitro flowering and fruiting in culture of Dendrobium officinate [sic] Kimura et Migo. (Orchidaceae). Pak. J. Bot. 46(5): 1877-1882.

RaO S., Barman B., 2014. In vitro micropropagation of Dendrobium chrysanthum Wall. ex Lindl. a threatened orchid. Scholars Acad. J. Biosci. 2(1): $39-42$.

Sharma K.K.R., Sharma B., Majumdar S., 2005. Micropropagation of Dendrobium fimbriatum Hook. by green pod culture. J. Plant Biol. 48: 253-257.

Sharma U., Rama Rao V., Mohan J.S.S., Reddy A.S., 2007. In vitro propagation of Dendrobium microbulbon A. Rich - A rare ethnomedicinal herb. Indian J. Biotechnol. 6: 381-384.

Soares J.S., Rosa Y.B.C.J., Suzuki R.M., Scalon S.P.Q., Rosa Junior E.J., 2012. Germinação assimbiótica e desenvolvimento de Dendrobium nobile Lindl. sob efeito de reguladores vegetais no tratamento prégerminativo. Rev. Bras. Plantas Med. 14: 617-623 (in Portuguese with English abstract).
Soares J.S., Rosa Y.B.C.J., Suzuki R.M., Scalon S.P.Q., Rosa Junior E.J., 2013. In vitro cultivation of Dendrobium nobile using coconut water in the culture medium. Hortic. Bras. 31(1): 63-67 (in Portuguese with English abstract).

Soetopo L., Purnamaningisin S.L., 2012. Dendrobium and Phalaenopsis germplasms conservation by cloning technology. Agrivita J. Agric. Sci. 34 (2): $115-126$.

Soundararajan T., 2009. Micropropagation studies on Bacopa monnieri, Nerium oleander and Bioreactor studies on micropropagation of Dendrobium, an orchid. $\mathrm{PhD}$ thesis, Bharath University, India, $191 \mathrm{p}$.

Stewart S., Zettler L., Minso J., Brown P., 2003. Symbiotic germination and reintroduction of Spiranthes brevilabris Lindley, an endangered orchid native to Florida. Selbyana 24: 64-70.

Su Z., WANG C.B., 2014. Tissue culture propagation techniques of Dendrobium dixanthum. For. Inventory Planning 39(6): 160-163.

SugII N.C., 2011. The establishment of axenic seed and embryo cultures of endangered Hawaiian plant species: special review of disinfection protocols. In Vitro Cell. Dev. Biol. - Plant 47: 157-169.

SujJaritthurakarn P., Kanchanapoom K., 2011. Efficient direct protocorm-like bodies induction of dwarf Dendrobium using thidiazuron. Not. Sci. Biol. 3: 88-92.

Sunitibala H., Kishor R., 2009. Micropropagation of Dendrobium transparens L. from axenic pseudobulb segments. Indian J. Biotech. 8: 448-452.

Takamiya T., Wongsawad P., Tajima N., Shioda N., Lu J.F., Wen C.L., Wu J.B., Handa T., IiJima H., Kitanaka S., Yukawa T., 2011. Identification of Dendrobium species used for herbal medicines based on ribosomal DNA internal transcribed spacer sequence. Biol. Pharm. Bull. 34(5): 779-782.

Tan X.M., Wang C.L., Chen X.M., Zhou Y.Q., Wang Y.Q., Luo A.X., Liu Z.H., Guo S.X., 2014. In vitro seed germination and seedling growth of an endangered epiphytic orchid, Dendrobium officinale, endemic to China using mycorrhizal fungi (Tulasnella sp.). Sci. Hort. 165: 62-68.

Teixeira da Silva J.A., 2013. The role of thin cell layers in regeneration and transformation in orchids. Plant Cell Tiss. Org. Cult. 113(2): 149-161.

Teixeira da Silva J.A., Dobránszki J., 2013. Plant thin cell layers: a 40-year celebration. J. Plant Growth Reg. 32(4): 922-943.

Teixeira da Silva J.A., Dobránszki J., Cardoso J.C., Zeng S.J., 2015a. Dendrobium micropropagation: a review. Plant Cell Rep. 34(5): 671-704.

Teixeira da Silva J.A., Jin X.H., Dobránszki J., Lu J.J., Wang H.Z., Zotz G., CARdoso J.C., Zeng S.J., 2016. Advances in Dendrobium molecular research: applications in genetic variation, identification and breeding. Mol. Phylogen. Evol. 95: 196-216. 
Teixeira DA Silva J.A., Kulus D., 2014. Chrysanthemum biotechnology: discoveries from the recent literature. Folia Hort. 26(2): 67-77.

Teixeira da Silva J.A., Tsavkelova E., Ng T.B., Dobránszki J., Parthibhan S., Cardoso J.C., Rao M.V., Zeng S.J., 2015b. Asymbiotic in vitro seed propagation of Dendrobium. Plant Cell Rep. 34(10): 1685-1706.

Teixeira da Silva J.A., Tsavkelova E., Zeng S.J., NG T.B., Dobránszki J., Parthibhan S., Cardoso J.C., RAO M.V., 2015c. Symbiotic in vitro seed propagation of Dendrobium: fungal and bacterial partners and their influence on plant growth and development. Planta 242(1): 1-22.

Teixeira da Silva J.A., Winarto B., 2016. Somatic embryogenesis in two orchid genera (Cymbidium, Dendrobium). In: In Vitro Plant Embryogenesis in Higher Plants. M.A. Germanà and M. Lambardi (eds), Springer Science+Business Medium - Humana Press, Berlin, Germany: 371-386.

Traore A., Xing Z., Bonser A., Carlson J., 2005. Optimizing a protocol for sterilization and in vitro establishment of vegetative buds from mature Douglas fir trees. HortScience 40(5): 1464-1468.

Udomdee W., Wen P.J., Lee C.Y., Chin S.W., Chen F.Y., 2014. Effect of sucrose concentration and seed maturity on in vitro germination of Dendrobium nobile hybrids. Plant Growth Regul. 72: 249-255.

Unemoto L.K., Faria R.T., Destro D., Barbosa C.M., LONE A.B., 2009. Survival and differentiation of Oncidium flexuosum protocorm submitted to peracetic acid and colchicine treatment. Acta Scient. Agron. 31(3): 503-508 (in Portuguese with English abstract).

Vacin E., Went F.W., 1949. Some pH changes in nutrient solutions. Bot. Gaz. 110: 605-613.

Vijayakumar S., Rajalkshmi G., Kalimuthu K., 2012. Propagation of Dendrobium aggregatum through the culture of immature seeds from green capsules. Lankesteriana 12(2): 131-135.

Wang X.H., Cheng Y., TAn X., Zhang F.K., Li J.L., LiU G.M., 2013. In vitro rapid propagation Dendrobium officinale Kimura et Migo. J. Tropical Biol. 4(4): 374380.

Warcup J., 1981. The mycorrhizal relationships of Australian orchids. New Phytol. 87: 371-381.

Winarto B., Rachmawati F., 2013. In vitro propagation protocol of Dendrobium 'Gradita 31' via protocorm like bodies. Thammasat Int. J. Sci. Technol. 18(2): 54-68.

Winarto B., Rachmawati F., Santi A., Teixeira da Silva J.A., 2013. Mass propagation of Dendrobium 'Zahra FR 62', a new hybrid used for cut flowers, using bioreactor culture. Sci. Hortic. 161: 170-180.

Winarto B., Teixeira da Silva J.A., 2012. Sterilization procedures for in vitro culture of leatherleaf fern (Rumohra adiantiformis). Int. J. Plant Dev. Biol. 6(1):46-50.

Winarto B., Teixeira da Silva J.A., 2015. The use of coconut water and fertilizer for the in vitro proliferation and plantlet production of Dendrobium 'Gradita 31'. In Vitro Cell. Dev. Biol. - Plant 51(3): 303-314.

YANG N., Chen Z.L., DuAn J., Zeng S.J., 2006. In vitro propagation of Dendrobium cochliodes Schltr. Plant Physiol. Commun. 42(2): 248.

Yao C., Li Z.S., Li W.S., Gen X.Y., Bai Y.B., Zhou H.G., 2015. Research on the tissue culture and rapid propagation technology of Dendrobium falconeri Hook. J. Anhui Agri. Sci. 43(30): 33-34, 69 (in Chinese with English abstract).

Yeoman M.M., Macleod A.J., 1977. Tissue (callus) culture technique. In: Plant Tissue and Cell Culture. H.E. Street (ed.), Blackwell Scientific Publications, Oxford: 31-59.

Zhao D., Hu G., Chen Z., Shi Y., Zheng L., Tang A., LoNG C., 2013. Micropropagation and in vitro flowering of Dendrobium wangliangii: A critically endangered medicinal orchid. J. Med. Plant Res. 7(28): 2098-2110.

Zhao M.M., Zhang G., Zhang D.W., Hsiao Y.Y., Guo S.X., 2013. ESTs analysis reveals putative genes involved in symbiotic seed germination in Dendrobium officinale. PLoS ONE 8: 1-10.

Zhao P., Wu F., Feng F.S., Wang W.J., 2008. Protocormlike body (PLB) formation and plant regeneration from the callus culture of Dendrobium candidum Wall ex Lindl. In Vitro Cell. Dev. Biol. - Plant 44: 178-185.

Zhou X.K., Lan S.R., Peng D.H., Wu S.S., Jiang M.T., Zhang L.Y., 2014. In vitro tissue culture and plant regeneration from mature embryos of Dendrobium warkianum. J. Fujian Coll. Forestry 34(4): 289-296.

Received November 15, 2015; accepted February 28, 2016 